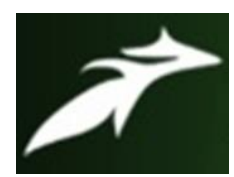

Abdul Wahab Walizada et al, International Journal of Advances in Agricultural Science and Technology,

Vol.7 Issue.12, December-2020, pg. 81-97

ISSN: 2348-1358

Impact Factor: 6.057

NAAS Rating: 3.77

\title{
Effect of Herbicides and their Mixtures on Broad Leaf Weeds and Yield of Wheat
}

\author{
Abdul Wahab Walizada ${ }^{1}$; V. S. Hooda ${ }^{2}$; Charul Chaudhary $^{3}$; Meenakshi Sangwan ${ }^{4}$; Satyajeet $^{5}$ \\ ${ }^{1}$ M. Sc. Scholar, Department of Agronomy, CCSHAU, Hisar, Haryana (India); \\ ${ }^{2}$ Assistant Scientist, Department of Agronomy, CCSHAU, Hisar, Haryana (India); \\ ${ }^{3} \mathrm{Ph}$. D. Scholar, Department of Agronomy, CCSHAU, Hisar, Haryana (India); \\ ${ }^{4}$ District Extension Specialist, KVK, Rohtak (CCSHAU), Haryana (India); \\ ${ }^{5}$ Assitant Scientist (Agronomy), RRS, Bawal (CCSHAU), Haryana (India) \\ *Corresponding Author (Email- vshooda79@gmail.com) \\ DOI: 10.47856/ijaast.2020.v07i12.012
}

\begin{abstract}
A field study was conducted at Agronomy Research Farm of CCS Haryana Agricultural University, Hisar during Rabi season of 2016-17. The experiment comprised of five post emergence herbicides (metsulfuron, carfentrazone, 2, 4-D Ester, pyroxsulam and halauxifen) and their mixtures at different doses along with weedy check and weed free treatment. Application of halauxifen + pyroxsulam sprayed at $23.96 \mathrm{~g} / \mathrm{ha}$ at 35 days after sowing was the most effective treatment to control the broad leaf weeds in wheat with higher weed control efficiency. Application of the herbicides halauxifen + pyroxsulam at $23.96 \mathrm{~g} / \mathrm{ha}$, metsulfuron +2 , 4-D Ester at $(3+500 \mathrm{~g} / \mathrm{ha})$ and halauxifen + pyroxsulam at $19.17 \mathrm{~g} / \mathrm{ha}$ significantly increased the dry matter accumulation of wheat and plant height compared to weedy check. Application of halauxifen + pyroxsulam at $23.96 \mathrm{~kg} / \mathrm{ha}$, metsulfuron + 2, 4-D Ester at $3+500 \mathrm{~g} / \mathrm{ha}$ and carfentrazone $+2,4-\mathrm{D}$ Ester at $15+500 \mathrm{~g} / \mathrm{ha}$ resulted into higher number of tillers per meter row length. Halauxifen + pyroxsulam sprayed at $23.96 \mathrm{~g} / \mathrm{ha}$ at 35 days after sowing resulted into higher grain yield of $5395 \mathrm{~kg} / \mathrm{ha}$, straw yield of $8466 \mathrm{~kg} / \mathrm{ha}$ and biological yield of $13861 \mathrm{~kg} / \mathrm{ha}$ followed by metsulfuron +2 , 4-D Ester at $3+500 \mathrm{~g} / \mathrm{ha}$ and carfentrazone + 2, 4-D Ester at $15+500 \mathrm{~g} / \mathrm{ha}$.
\end{abstract}

Keywords: "Wheat, herbicide mixture, carfentrazone, halauxifen, metsulfuron, pyroxosulam" 


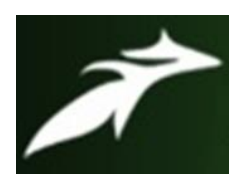

Abdul Wahab Walizada et al, International Journal of Advances in Agricultural Science and Technology, Vol.7 Issue.12, December-2020, pg. 81-97

ISSN: 2348-1358

Impact Factor: 6.057

NAAS Rating: 3.77

\section{Introduction}

In India, wheat (Triticum aestivum L.) is one of the most important cereal crop and staple food after rice and for food security, its assured production and supply are necessary. Annual wheat production of our country has been estimated at 103.60 million tonnes from 29.32 million hectare (13.43\% of global area) registering an all-time highest crop productivity of $3533 \mathrm{~kg} \mathrm{ha}^{-1}$ (ICAR-IIWBR 2019, Director's Report of AICRP on wheat and barley). In Haryana state, it is grown over an area of about 2.56 million hectares with production of 12.4 million tonnes and a productivity of $4841 \mathrm{~kg} / \mathrm{ha}$ (Anonymous, 2018). In the current scenario, the main emphasis would be on increasing the productivity of wheat by adopting the improved cultivation practices as there is hardly any scope for expansion of area under wheat. The productivity of wheat in most of the northern states i.e. Punjab, Haryana and U.P. etc. has stagnated for which number of factors responsible for the stagnation of wheat productivity, among these weeds contribution is maximum. If agronomic practices are fine tuned and weeds are managed properly, the wheat productivity can be enhanced further which will be very helpful for feeding the ever increasing population.

For achieving potential yield of wheat, weeds are one of the major constraints and the losses caused by weeds vary with the weed species, their density and environmental factors. Wheat is generally infested with both grassy and broadleaf weeds depending upon environmental conditions like humidity, temperature and moisture availability, type of soil, cultural practices and crop rotation adopted. Weeds in wheat cause severe competition for essential nutrients, moisture and space thus reducing wheat yield and also its quality significantly. Adoption of high yielding dwarf wheat varieties combined with increased use of chemical fertilizers and improved irrigation facilities have resulted in shifts in weed flora in wheat crop. Broadleaf weeds are becoming a problem in area where grassy herbicides (clodinafop, fenoxaprop and pinoxaden) without supplementing with broadleaf weed herbicides are used continuously. Among broadleaf weeds, toothed dock (Rumex dentatus) and field bindweed (Convolvulus arvensis) are also a major problem in wheat crop. 


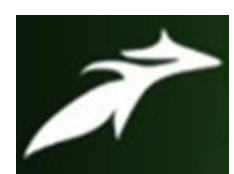

Abdul Wahab Walizada et al, International Journal of Advances in Agricultural Science and Technology, Vol.7 Issue.12, December-2020, pg. 81-97

ISSN: 2348-1358

Impact Factor: 6.057

NAAS Rating: 3.77

In wheat, the earlier period up to 30-40 days is critical period for weed control. Weed management is one of the major input costs of crop production and weeds can be controlled by adopting different methods; however, each weed control method has its limitations. Mechanical methods are laborious and time consuming, besides weeds with similar morphological characters like crops are likely to be escaped. Because of higher economic cost of labour for manual weeding and its lower efficacy, farmers are relying heavily on herbicides for effective weed control in different crops including wheat. Generally, a herbicide is more effective against some of the weeds and less or not effective against others. Herbicides have benefited the agricultural community in many ways; however, heavy reliance on herbicides creates an environment favourable for weed resistance to herbicides, weed population shifts and off-site movements of herbicides (Rao and Nagmani, 2010). A number of weed species that were once susceptible to and easily managed by certain herbicides have developed resistance with time and these weeds are no longer controlled by application of previously effective herbicides. As a result the repeated use of a specific type of a herbicide on a same land has developed resistance in some type of weeds to these chemicals. Extensive use of isoproturon over many years has led to the evolution of resistance in Phalaris minor in north-west India. Therefore, continued use of isoproturon after the development of resistance resulted in heavy build up of Phalaris minor population and caused heavy yield losses in wheat (Chhokar and Malik, 2002). The control of weeds through chemicals is considered more suitable as they cover more area during short period of time. Keeping the importance of these circumstances in view, it is necessary to select suitable chemicals capable of controlling effectively and economically all the weeds present in wheat field. Nowadays, herbicides such as pendimethalin, metribuzin, 2, 4-D etc, are used for weed control in wheat along with cultural and mechanical methods.

In India, three major herbicides used are metsulfuron, 2, 4-D and carfentrazone to control broadleaf weeds in wheat (Chhokar et al., 2007). Also, some of the post-emergent contact herbicides like carfentrazone-ethyl, are less effective on weeds having advanced stage, as well as, unable to control the subsequent weeds emerging after application due to its lack of residual activity (half life of carfentrazone is 2-5 days) in soil (Willis et al., 2007). 


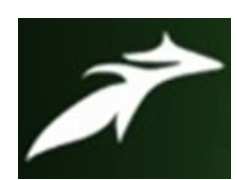

Abdul Wahab Walizada et al, International Journal of Advances in Agricultural Science and Technology,

Vol.7 Issue.12, December-2020, pg. 81-97

ISSN: 2348-1358

Impact Factor: 6.057

NAAS Rating: 3.77

However, the sole dependence on herbicide of single mode of action is also not advisable as it has contributed to shift towards difficult-to-control weeds and the rapid evolution of multiple herbicide resistance, which is a threat to wheat production (Malik and Singh, 1995 and Singh, 2007). The cost of application is increased in sequential application and efforts should be made to use a suitable combination of more than one herbicide to combat noxious weeds like Phalaris minor along with broadleaf weeds by lowering the cost of herbicide without losing weed control efficacy (Singh, 2009 and Singh et al., 2011). Also, introduction of herbicides with new mode of action has slowed down, therefore, there is need to use mixture of existing herbicides in a way to lower the load on environment and improve weed control efficacy without any adverse effect on crop. The benefits and consequences of herbicides mixtures are apparent and should be adhered to while recommending a mixture of more than one herbicide (Singh, 2009 and Singh et al., 2011). Use of herbicide mixture combinations is advisable to broaden the spectrum of weed kill and to provide the long term residual weed control. Herbicide mixture besides providing control of complex weed flora will also help in managing and delaying the herbicide resistance problem. Greater knowledge of herbicide mixtures against weeds in wheat crops may allow a better understanding of differences occurred among various studies and would aid in development of weed management strategies as components of more comprehensive integrated weed management programs. Due to availability of limited information on herbicide mixtures to control broad leaf weeds in wheat, the present study was carried out to evaluate effect of some herbicides and their mixtures on broad leaf weeds and yield of wheat.

\section{Methodology:}

The field experiment was conducted at Agronomy Research Farm of CCS Haryana Agricultural University, Hisar during Rabi season of 2016-17. The experimental site is located at $29^{\circ} 16^{\prime} \mathrm{N}$ latitude and $75^{\circ} 7^{\prime} \mathrm{E}$ longitude at the mean sea elevation of $215.2 \mathrm{~m}$ in north-west part of India. The climate of the area is semiarid type, with very hot summers and relatively cool winters and main characteristics of climate in Hisar are dryness, extremes of temperature, and scanty rainfall. During summer, the maximum daytime temperature varies 


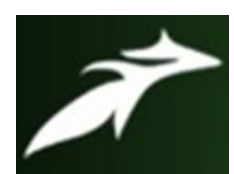

Abdul Wahab Walizada et al, International Journal of Advances in Agricultural Science and Technology, Vol.7 Issue.12, December-2020, pg. 81-97

ISSN: 2348-1358

Impact Factor: 6.057

NAAS Rating: 3.77

between 40 and $46{ }^{\circ} \mathrm{C}\left(104\right.$ and $\left.115^{\circ} \mathrm{F}\right)$ while during winter, it ranges between 1.5 and $4{ }^{\circ} \mathrm{C}$. Relative humidity varies from 5 to $100 \%$. Hisar is located on the outer margins of the southwest monsoon region having average annual rainfall around $429 \mathrm{~mm}$ (16.9 in), most of which occurs during July and August. The texture of the surface soil of the experimental field was sandy loam, that was low in organic carbon and nitrogen, medium in available phosphorus, high in potassium and slightly alkaline $(\mathrm{pH} 7.73)$ in reaction. Wheat variety WH 1105 was sown on 04.11 .2016 by seed-cum-fertilizer drill with a spacing of $20 \mathrm{~cm}$ from line to line at 5-6 cm depth using $100 \mathrm{~kg}$ seed $\mathrm{ha}^{-1}$ and harvesting was done on 11.04.2017. The experiment was laid in randomized block design with three replications and comprised of five post emergence herbicides (metsulfuron, carfentrazone, 2, 4-D Ester, pyroxsulam and halauxifen) and their mixtures at different doses along with weedy check and weed free treatment (Table 1). All the herbicides and their mixtures were applied at 35 days after sowing (DAS) of the crop by using flat fan nozzle mounted on a knapsack sprayer with a spray discharge of 375 liter/ha. Observations for total weed density were recorded by randomly placing quadrate $\left(0.25 \mathrm{~m}^{2}\right)$ in each plot at different intervals. Major weed flora in experiment includes Anagallis arvensis, Chenopodium album, Melilotus indicus, Medicago denticulata, Rumex dentatus and other miscellaneous weeds (Lathyrus aphaca, Convolvulus arevensis, Cirsium arvense etc.). For calculating dry matter accumulation $\left(\mathrm{g} / \mathrm{m}^{2}\right)$ of weeds, the weeds taken with a quadrate were dried in oven at $65 \pm 5{ }^{\circ} \mathrm{C}$. The dried samples were weighed and expressed as $\mathrm{g} / \mathrm{m}^{2}$. Weed control efficiency was calculated with the help of formula:

$$
\operatorname{WCE}(\%)=\frac{\mathrm{W}_{2}-\mathrm{W}_{1}}{\mathrm{~W}_{2}} \times 100
$$

Where,

$\mathrm{W}_{2}=$ Dry weight of weeds in weedy check plot

$\mathrm{W}_{1}=$ Dry weight of weeds in treatment plot

The plant height of three tagged plants from each plot were measured from soil surface to growing point at $90 \mathrm{DAS}$ and up to spike at $120 \mathrm{DAS}$ and at harvest of crop. Average plant height $(\mathrm{cm})$ was used for statistical analysis. The herbicide toxicity on crop stand and growth was recorded at 7, 15, 30, 45 and 60 days after treatment on the scale of 0 to 10 . Number of 


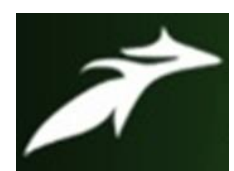

Abdul Wahab Walizada et al, International Journal of Advances in Agricultural Science and Technology,

Vol.7 Issue.12, December-2020, pg. 81-97

ISSN: 2348-1358

Impact Factor: 6.057

NAAS Rating: 3.77

tillers were counted at 60,90 and 120 DAS from one meter row length at three places per plot and converted into per meter square. Leaves were separated from five randomly harvested plants to measure leaf area ( $\mathrm{cm}^{2} /$ plant) with the help of LI 3000 area meter (LICOR LTD., Nabraska, USA) at 30, 60, 90 and 120 DAS . The LAI was worked out with the help of following formula:

\section{Leaf area $\left(\mathrm{cm}^{2}\right)$}

Leaf Area Index $=$

\section{Land area $\left(\mathrm{cm}^{2}\right)$}

For taking dry matter accumulation of plants, the plants were harvested from $0.25 \mathrm{~cm}$ row length from two places at 60,90 and 120 DAS. The above total ground portion of the plant samples was washed in water and dried in hot air oven at $65{ }^{0} \mathrm{C}$ separately. The mean dry weight of plant was recorded and converted in grams per $\mathrm{m}^{2}$. After harvesting the net area of individual plot, the bundles were sun dried for 4-5 days and weight from each plot before threshing. It was recorded separately as biological yield with the help of weighing balance and converted into $\mathrm{kg} \mathrm{ha}^{-1}$. The biomass obtained for individual net plot after sun drying (biological yield) was threshed and weighed for grain yield $\left(\mathrm{kg} \mathrm{ha}^{-1}\right)$. The grain yield so obtained was deducted from the biomass of the harvested crop to compute the straw yield. The experimental data were statistically analyzed by the methods of analysis of variance (ANOVA) as described by Panse and Sukhatme (1985).

\section{Results and Discussion:}

\section{Efficacy of herbicides on broad leaf weeds}

Herbicide and their mixtures resulted into significantly decreased total population of the broad leaf weeds and their dry weight resulting into higher weed control efficiency (Table 1). The most prominent herbicides mixtures treatment which reduced the weed density and dry weight of the broad leaf weeds was halauxifen + pyroxulam at $23.96 \mathrm{~g} / \mathrm{ha}$. Other treatments were almost at par with each other in reduction of weed density and dry weight of broad leaf weeds at different time interval. Highest weed control efficiency was estimated under weed free conditions 


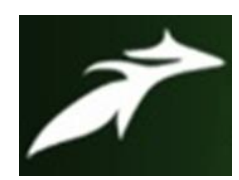

Abdul Wahab Walizada et al, International Journal of Advances in Agricultural Science and Technology, Vol.7 Issue.12, December-2020, pg. 81-97

ISSN: 2348-1358

Impact Factor: 6.057

NAAS Rating: 3.77

$(100.0 \%)$ followed by halauxifen + pyroxsulam at $23.96 \mathrm{~g} / \mathrm{ha}$, carfentrazone +2 , 4-D Ester at $15+500 \mathrm{~g} / \mathrm{ha}$, metsulfuron +2 , 4-D Ester at $3+500 \mathrm{~g} / \mathrm{ha}$ and metsulfuron + carfentrazone at $4+20 \mathrm{~g} / \mathrm{ha}$ and lowest among the herbicides pyroxsulam at $18.75 \mathrm{~g} / \mathrm{ha}$ as compared to weedy check (Table 1). The herbicides like metsulfuron, carfentrazone, 2, 4-D Ester, pyroxasulam and halauxifen all were systemic and can control the weeds efficiently. However, halauxifen + pyroxsulam at $23.96 \mathrm{~g} / \mathrm{ha}$ resulted into maximum weed control efficiency than the other herbicides and their mixtures. The reason may be the synergistic effect of the herbicides to control the associated weeds in wheat. Similar results have been reported by Mahamoud et al. (2016).

\section{Effect of herbicides and their mixture on plant phytotoxicity}

Phytotoxicity was checked at 7, 15, 30, 45 and 60 days after treatment of herbicides and their mixtures on wheat plants (Table 2). Maximum phytotoxicity score (2.50) was observed in the wheat plants where carfentrazone +2 , 4-D Ester was applied at $15+500 \mathrm{~g} / \mathrm{ha}$ followed by its sole application at $20 \mathrm{~g} / \mathrm{ha} \mathrm{(2.25)}$ and its combination with 2, 4-D Ester at 15 $+400 \mathrm{~g} / \mathrm{ha}(2.25)$ at 7 days after treatment. Tomlin (2003) reported that 2, 4-D plus carfentrazone-ethyl in a mixture of phenoxyactitic (auxin type) herbicides is capable of affecting the gene action and cause chlorosis at the growing points, growth inhibition, wilting and necrosis and also is a protoporphyrinogen oxidase inhibitor, leading to membrane disruption.

Metsulfuron at $4 \mathrm{~g} / \mathrm{ha} ; 2,4-\mathrm{D}$ Ester at $500 \mathrm{~g} / \mathrm{ha}$ and pyroxsulam at $18.75 \mathrm{~g} / \mathrm{ha}$ when applied as sole sprays at 35 days after sowing in wheat as post emergence herbicide did not show any phytotoxic effect on wheat at 7, 15, 30, 45 and 60 days after treatment. Halauxifen at $5.21 \mathrm{~g} / \mathrm{ha}$ as sole resulted in phytotoxity in wheat with a mean score of 0.50 at 7 days after treatment and it reduced to 0.25 at 15 days after treatment. There were no phytotoxic effects in wheat after 15 days its application. Halauxifen + pyroxsulam at $19.17 \mathrm{~g} / \mathrm{ha}$ was constant in its phytotoxic effect at 7 and 15 days after treatment and it was 0.50 during both the intervals. However, when the dose increased from $19.17 \mathrm{~g} /$ ha to $23.96 \mathrm{~g} / \mathrm{ha}$, the phytotoxic effect was reduced from 0.50 at 7 days after treatment to 0.25 at 15 days after treatment. The reason is that halauxifen belongs to phenoxyalkanoic acids family which only works at lower doses. 


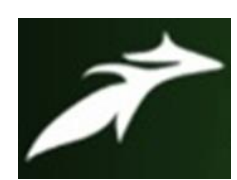

Abdul Wahab Walizada et al, International Journal of Advances in Agricultural Science and Technology,

Vol.7 Issue.12, December-2020, pg. 81-97

ISSN: $2348-1358$

Impact Factor: 6.057

NAAS Rating: 3.77

Hence increased dose led to lesser phytotoxic effect in wheat in combination with pyroxsulam which belong triazopyrimidin sulfonamide (TSA) herbicide and are ALS inhibitors.

Carfentrazone in sole application at $20 \mathrm{~g} / \mathrm{ha}$ resulted into phytotoxicity score from 2.25, 1.75 and 1 at 7, 15 and 30 days after treatment after which the phytotoxity reduced to zero at 45 and 60 days after treatment. But its combination with 2, 4-D and metsulfuron were found less phytotoxic to wheat except highest phytotoxic effect with 2, 4-D Ester at $15+500$ g/ha. All the mixtures after 45 and 60 days after treatment showed no symptoms of phytotoxicity in wheat.

Lower phytotoxicity score in wheat may be due to its efficiency to metabolize the selective herbicides faster as compared to the associated broad leaf weeds like Chenopodium album; Anagallis arvensis only, not Medicago denticulata; Melilotus indicago; Rumex dentatus; Cirsium arvense; Lathyrus aphaca and Convolvulus arvensis. DeBoer et al. (2011) tested the selectivity of pyroxsulam in blackgrass and wheat and reported that root uptake of pyroxsulam in blackgrass was significantly higher than in wheat, which might be due to possible activity enhancement in blackgrass leading to root uptake. In contrast to this, in wheat, the translocation of pyroxsulam molecules from roots uptake and from foliage to inside the plant by foliar application was found comparable with blackgrass, resulting into the rapid metabolism of pyroxsulam in wheat and a less active form of pyroxsulam is formed an O-dealkylation product. Further, if safener like cloquintocet-mexyl when added along with the herbicide, then wheat metabolized pyroxsulam much faster. Cloquintocet-mexyl did not increase the rate of metabolism in blackgrass.

Weed control strategy include the mixture of the herbicides to reduce the application cost (Kudsk, 2002) and to reduce the chances of herbicide resistance (Lucchin et al., 2001).

\section{Effect of herbicides and their mixture on various growth parameters of wheat}

Weed free condition in wheat resulted into taller plants, higher number of tillers, more LAI along with more dry matter accumulation as compared to all other treatments (Table 3 and Fig. 1). But to see the alternate of weed free condition in practical due to higher labour costs, chemical control were felt necessary. Post emergence herbicides were the best alternate 




Abdul Wahab Walizada et al, International Journal of Advances in Agricultural Science and Technology, Vol.7 Issue.12, December-2020, pg. 81-97

ISSN: $2348-1358$

Impact Factor: 6.057

NAAS Rating: 3.77

to curb the growth of the broad leaf weeds which fetch most of the nutrients in wheat. Plant heights of wheat was significantly improved after the application of the herbicides halauxifen + pyroxsulam at $23.96 \mathrm{~g} / \mathrm{ha}$ followed by metsulfuron +2 , 4-D Ester at $3+500 \mathrm{~g} / \mathrm{ha}$ ) and halauxifen + pyroxsulam at $19.17 \mathrm{~g} / \mathrm{ha}$, respectively. Application of these herbicides also increased the number of tillers, LAI and dry matter accumulation. More leaf area was a result of available inputs to plants either from the soil or from the incoming solar radiation by which more photosynthates were assimilated and used in the growth of the plant in terms of more leaf area. Halauxifen is a systemic herbicide belongs to phenoxyalkanoic acids family and its mode of action as synthetic auxins and auxin transport inhibitor. Hence in combination of pyroxsulam, this herbicide inhibits the growth of the broad leaf weeds in the plots where they were applied. In addition to this, because auxins are responsible for cell division, elongation, apical dominance and many more functions in the plants. Use of auxin inhibitor herbicide like halauxifen resulted into inhibition of this plant growth hormone leading to death of the plant in case of weeds especially. Further, use of pyroxsulam along with halauxifen resulted into inhibition of ALS enzyme. Halauxifen herbicide binds to different sites on the ALS enzyme and stops its activity for the synthesis of different kinds of amino acids leading to death of the plant. Both the herbicides in mixtures performed well to reduce the weed intensity. Thus, less competition of weeds led to more plant height, higher number of tillers and more dry matter accumulation in wheat. Moreover, herbicides used in mixtures may create synergistic effects and may alter the balance of the ecosystem. Similar results have been obtained by Khan et al. (2003).

\section{Effect of herbicides and their mixture yield attributes and yield of wheat}

Significantly higher wheat yields (grain, straw and biological yield) along with better yield attributes were observed in weed free plots of wheat followed by halauxifen + pyroxsulam at $23.96 \mathrm{~g} / \mathrm{ha}$ which resulted into highest grain yield $5395 \mathrm{~kg} / \mathrm{ha}$, straw yield $8466 \mathrm{~kg} / \mathrm{ha}$, biological yield $13861 \mathrm{~kg} / \mathrm{ha}$ (Table 4). Halauxifen + pyroxsulam and weed free were at par with each other but were significantly higher than all other treatments. Halauxifen + pyroxsulam at $23.96 \mathrm{~g} / \mathrm{ha}$ was found to be most suitable treatment in terms of grain, straw and biological yield and yield attributes of wheat (Table 4). Biological yield meant for all 


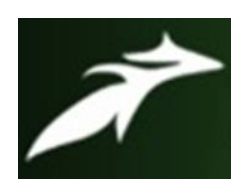

Abdul Wahab Walizada et al, International Journal of Advances in Agricultural Science and Technology,

Vol.7 Issue.12, December-2020, pg. 81-97

ISSN: 2348-1358

Impact Factor: 6.057

NAAS Rating: 3.77

over biomass production which is a function of initial growth and biomass production of a crop. Weeds compete for the applied inputs but in wheat especially the broad leaf weeds are the main problem which use mostly the available input and space and resulted into significant loss in the economic yield. The mixtures of the above herbicides significantly controlled the weeds after their spray at 35 days after sowing, resulting in increased in biological yield, grain yield and straw yield. Similar results have been confirmed by Pratap et al. (2010) where they applied pyroxsulam (12 to $30 \mathrm{~g}$ ) in wheat which increased the grain yield in both the concentration (3.0 and 3.6\% O.D.). Similarly, Mahamoud et al. (2016) also reported that application of herbicides halauxifen-methyl + florasulam (paradigm) gave 100\% reduction in fresh weight of broad leaf weeds at both locations.

\section{Conclusion:}

So, it can be concluded that application of herbicide mixtures was found more effective in controlling the broad leaf weeds in wheat as compared to their sole application. To control the broad leaf weeds in wheat, application of halauxifen + pyroxsulam sprayed at $23.96 \mathrm{~g} / \mathrm{ha}$ at 35 days after sowing was the most effective treatment with higher grain yield of $5395 \mathrm{~kg} / \mathrm{ha}$, straw yield of $8466 \mathrm{~kg} / \mathrm{ha}$ and biological yield of $13861 \mathrm{~kg} / \mathrm{ha}$ with highest weed control efficiency followed by metsulfuron +2 , 4-D Ester $(3+500 \mathrm{~g} / \mathrm{ha})$ and carfentrazone + 2, 4-D Ester $(15+500 \mathrm{~g} / \mathrm{ha})$.

\section{References}

[1]. Anonymous. 2018. Statistical Abstract of Haryana 2017-18. Issued by Department of Economic and Statistical Analysis, Haryana. pp 13. Retrieved from http://esaharyana.gov.in/Portals/0/ABSTRACT\%2017-18\%28English\%29.pdf

[2]. Chhokar, R. S. and Malik, R. K. 2002. Isoproturon-resistant little seed canary grass (Phalaris minor) and its response to alternate herbicides. Weed Technology, 16, 166-173.

[3]. Chhokar, R. S., Sharma, R. K., Jat, G. R., Pundir, A. K. and Gathala, M. K. 2007. Effect of tillage and herbicides on weeds and productivity of wheat under rice-wheat growing system. Crop Protection, 26, 1689-1696.

[4]. DeBoer, G. J., Thornburgh, S., Gilbert, J., and Gast, R. E. 2011. The impact of uptake, translocation and metabolism on the differential selectivity between blackgrass and wheat for the herbicide pyroxsulam. Pest Management Science, 67(3), 279-286.

[5]. ICAR-IIWBR. 2019. Director's Report of AICRP on wheat \& Barley 2018/19 Ed. G.P. Singh. ICARIndian Institute of Wheat and Barley Research, Karnal, Haryana, India. P. 87.

[6]. Khan, M. H., Hassan, G., Khan, N., and Khan, M. A. 2003. Efficacy of different herbicides for controlling broadleaf weeds in wheat. Asian Journal of Plant Science, 2(3), 254-256. 


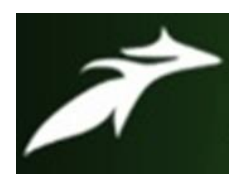

Abdul Wahab Walizada et al, International Journal of Advances in Agricultural Science and Technology,

Vol.7 Issue.12, December-2020, pg. 81-97

ISSN: 2348-1358

Impact Factor: 6.057

NAAS Rating: 3.77

[7]. Kudsk, P. 2002. Optimising herbicide performance. In: Naylor, R.E.L. (Ed.), Weed Management Handbook. Blackwell Science, Oxford, pp. 323-344.

[8]. Lucchin, M., Zanin, G. and Parrini, P. 2001. Resistenza delle malerbe agli erbicidi. In: Catizone, P., Zanin, G. (Eds.), Malerbologia. Pa` tron Editore, Bologna, Italy, pp. 487-521.

[9]. Mahamoud, S. M., Soliman, F. S. and Elsheik, M. 2016. Combination of halauxifen-methyl + florasulamwith other grassy herbicides against complex weed flora in wheat (Triticum aestivum). Journal of Plant Protection and Pathology, Mansoura University, 7 (5), 315- 320.

[10].Malik, R. K. and Singh, S. 1995. Littleseed canary grass (Phalaris minor) resistance to isoproturon in India. Weed Technology, 9, 419-425.

[11].Panse, V. G. and Sukhatme, P. V. 1985. Statistical method for agricultural workers. ICAR Publication, New Delhi.

[12].Partap, V. S., Dhani, V. C., Singh, S. P., Kumar, A., Singh, M. K. and Tripathi, N. 2010. Bioefficacy of Pyroxsulam (XDE-742) for weed control in wheat ( Triticum aestivum L.). Indian Journal of Weed Science, 42, (95-97).

[13].Rao, A. N. and Nagamani, A. 2010. Integrated Weed Management in India- Revisited. Indian Journal of Weed Science, 42 (3 \& 4), 123-135.

[14].Singh, S. 2007. Role of management practices on control of isoproturon-resistant little seed canary grass (Phalaris minor) in India. Weed Technology, 21, 339-346.

[15].Singh, S. 2009. Synergy of tank mix application of herbicides on Canada thistle (Cirsium arvense) under non-cropped situation. Indian Journal of Weed Science, 41, 88-95.

[16].Singh, S., Punia, S. S., Yadav, A. and Hooda, V. S. 2011. Evaluation of carfentrazone ethyl+metsulfuron-methyl against broadleaf weeds of wheat. Indian Journal of Weed Science, 43,1222.

[17].Tomlin, C. D. S. 2003. The Pesticide Manual, A World Compendium. BCPC Publications, Hampshire, UK.

[18].Willis, J. B., Askew, S. D. and McElroy, J. S. 2007. Improved white clover control with mesotrione by tank- mixing bromoxynil, carfentrazone and simazine. Weed Technology, 21, 739-743. 
Abdul Wahab Walizada et al, International Journal of Advances in Agricultural Science and Technology,

Vol.7 Issue.12, December-2020, pg. 81-97

ISSN: 2348-1358 Impact Factor: 6.057 NAAS Rating: $\mathbf{3 . 7 7}$

Table 1: Effect of herbicides and their mixtures on weed population, dry weight of weeds and weed control efficiency in wheat

\begin{tabular}{|c|c|c|c|c|c|c|c|}
\hline \multirow[t]{2}{*}{ Treatments } & \multirow[t]{2}{*}{ Dose } & \multicolumn{4}{|c|}{ Total broad leaf weed population $\left(\mathrm{No.} / \mathrm{m}^{2}\right)$} & \multirow{2}{*}{$\begin{array}{c}\begin{array}{c}\text { Total weed } \\
\text { dry weight } \\
\left(\mathrm{g} / \mathrm{m}^{2}\right)\end{array} \\
90 \mathrm{DAS}\end{array}$} & \multirow{2}{*}{$\begin{array}{c}\text { Weed } \\
\text { control } \\
\text { efficiency } \\
(\%)\end{array}$} \\
\hline & & 30 DAS & 60 DAS & 90 DAS & 120 DAS & & \\
\hline $\mathrm{T}_{1}:$ Metsulfuron & $4 \mathrm{~g} / \mathrm{ha}$ & $12.12(146.0)$ & $6.69(43.7)$ & $6.31(38.8)$ & $5.97(34.6)$ & $7.33(52.7)$ & 76.3 \\
\hline $\mathrm{T}_{2}:$ Carfentrazone & $20 \mathrm{~g} / \mathrm{ha}$ & $11.87(140.0)$ & $7.56(56.1)$ & $7.13(49.8)$ & $6.64(43.1)$ & $8.29(67.7)$ & 69.6 \\
\hline $\mathrm{T}_{3}: 2,4-\mathrm{D}$ Ester & $500 \mathrm{~g} / \mathrm{ha}$ & $12.08(145.0)$ & $6.54(41.8)$ & $6.18(37.2)$ & $5.91(33.9)$ & $7.18(50.6)$ & 77.3 \\
\hline $\begin{array}{l}\mathrm{T}_{4}: \text { Metsulfuron }+ \\
\text { carfentrazone }\end{array}$ & $4+20 \mathrm{~g} / \mathrm{ha}$ & $11.83(139.0)$ & $4.06(15.5)$ & $3.73(12.9)$ & $3.52(11.4)$ & $4.30(17.5)$ & 92.1 \\
\hline $\mathrm{T}_{5}:$ Metsulfuron $+2,4$-D Ester & $3+400 \mathrm{~g} / \mathrm{ha}$ & $12.37(152.0)$ & $5.25(26.6)$ & $5.08(24.8)$ & $4.89(22.9)$ & $5.89(33.7)$ & 84.9 \\
\hline $\mathrm{T}_{6}:$ Metsulfuron+ 2,4-D Ester & $3+500 \mathrm{~g} / \mathrm{ha}$ & $12.12(146.0)$ & $3.41(10.6)$ & $3.16(9.0)$ & $3.05(8.3)$ & $3.64(12.2)$ & 94.5 \\
\hline $\begin{array}{l}\mathrm{T}_{7}: \text { Carfentrazone }+2,4-\mathrm{D} \\
\text { Ester }\end{array}$ & $\begin{array}{c}15+400 \\
\mathrm{~g} / \mathrm{ha}\end{array}$ & $12.17(147.0)$ & $5.90(33.8)$ & $5.60(30.4)$ & $5.31(27.2)$ & $6.51(41.3)$ & 81.4 \\
\hline $\begin{array}{l}\mathrm{T}_{8}: \text { Carfentrazone }+2,4-\mathrm{D} \\
\text { Ester }\end{array}$ & $\begin{array}{c}15+500 \\
\text { g/ha }\end{array}$ & $12.12(146.0)$ & $3.15(8.9)$ & $2.98(7.9)$ & $2.81(6.9)$ & $3.43(10.7)$ & 95.2 \\
\hline $\mathrm{T}_{9}:$ Halauxifen + pyroxsulam & $19.17 \mathrm{~g} / \mathrm{ha}$ & $143.0(12.00)$ & $6.15(36.8)$ & $5.80(32.6)$ & $5.46(28.8)$ & $6.73(44.3)$ & 80.1 \\
\hline $\begin{array}{l}\mathrm{T}_{10}: \text { Halauxifen }+ \\
\text { pyroxsulam }\end{array}$ & $23.96 \mathrm{~g} / \mathrm{ha}$ & $12.08(145.0)$ & $2.30(4.3)$ & $2.00(3.0)$ & $2.00(3.0)$ & $2.25(4.1)$ & 98.2 \\
\hline
\end{tabular}


Abdul Wahab Walizada et al, International Journal of Advances in Agricultural Science and Technology,

Vol.7 Issue.12, December-2020, pg. 81-97

ISSN: 2348-1358 Impact Factor: 6.057 NAAS Rating: $\mathbf{3 . 7 7}$

\begin{tabular}{|c|c|c|c|c|c|c|c|}
\hline $\mathrm{T}_{11}$ : Pyroxsulam & $18.75 \mathrm{~g} / \mathrm{ha}$ & $12.00(143.0)$ & $8.05(63.8)$ & $7.54(55.8)$ & $7.11(49.5)$ & $8.77(75.8)$ & 65.9 \\
\hline $\mathrm{T}_{12}:$ Halauxifen & $5.21 \mathrm{~g} / \mathrm{ha}$ & $11.87(140.0)$ & $6.33(39.1)$ & $5.96(34.5)$ & $5.59(30.2)$ & $6.92(46.9)$ & 78.9 \\
\hline $\mathrm{T}_{13}:$ Weed free & -- & $0.0(1.00)$ & $0(1.00)$ & $0.0(1.00)$ & $0.0(1.00)$ & $0.0(1.00)$ & 100 \\
\hline $\mathrm{T}_{14}:$ Weedy check & & $12.25(149.0)$ & $14.04(196.0)$ & $12.85(164.0)$ & $12.12(146.0)$ & $14.96(222.7)$ & 0 \\
\hline $\mathrm{SEm} \pm$ & & 0.88 & 1.41 & 0.52 & 0.45 & 0.40 & -- \\
\hline C.D.at $5 \%$ & & 2.68 & 1.82 & 1.55 & 1.38 & 1.12 & -- \\
\hline
\end{tabular}

Original data given in parenthesis were subjected to square $\operatorname{root}(\sqrt{x+1})$ transformation before analysis

Table 2: Effect of herbicides and their mixtures on plant phytotoxicity (0-10 scale) in wheat

\begin{tabular}{|c|c|c|c|c|c|c|}
\hline \multirow[t]{3}{*}{ Treatments } & \multicolumn{6}{|c|}{ Plant phytotoxicity (0-10 scale) } \\
\hline & \multirow{2}{*}{ Dose } & \multicolumn{5}{|c|}{ Days after treatment } \\
\hline & & 7 & 15 & 30 & 45 & 60 \\
\hline $\mathrm{T}_{2}$ : Carfentrazone & $20 \mathrm{~g} / \mathrm{ha}$ & 2.25 & 1.75 & 1.00 & 0.00 & 0.00 \\
\hline $\mathrm{T}_{3}: 2,4$-D Ester & $500 \mathrm{~g} / \mathrm{ha}$ & 0.00 & 0.00 & 0.00 & 0.00 & 0.00 \\
\hline $\mathrm{T}_{4}:$ Metsulfuron + carfentrazone & $4+20 \mathrm{~g} / \mathrm{ha}$ & 2.00 & 2.00 & 0.50 & 0.00 & 0.00 \\
\hline
\end{tabular}


Abdul Wahab Walizada et al, International Journal of Advances in Agricultural Science and Technology,

Vol.7 Issue.12, December-2020, pg. 81-97

ISSN: 2348-1358 Impact Factor: 6.057 NAAS Rating: 3.77

\begin{tabular}{|c|c|c|c|c|c|c|}
\hline $\mathrm{T}_{6}:$ Metsulfuron+ 2,4-D Ester & $3+500 \mathrm{~g} / \mathrm{ha}$ & 0.50 & 0.50 & 0.50 & 0.00 & 0.00 \\
\hline $\mathrm{T}_{7}:$ Carfentrazone $+2,4$-D Ester & $15+400 \mathrm{~g} / \mathrm{ha}$ & 2.25 & 1.75 & 0.75 & 0.00 & 0.00 \\
\hline $\mathrm{T}_{8}:$ Carfentrazone $+2,4$-D Ester & $15+500 \mathrm{~g} / \mathrm{ha}$ & 2.50 & 2.25 & 0.75 & 0.00 & 0.00 \\
\hline $\mathrm{T}_{9}:$ Halauxifen + pyroxsulam & $19.17 \mathrm{~g} / \mathrm{ha}$ & 0.50 & 0.50 & 0.00 & 0.00 & 0.00 \\
\hline $\mathrm{T}_{10}:$ Halauxifen + pyroxsulam & $23.96 \mathrm{~g} / \mathrm{ha}$ & 0.50 & 0.25 & 0.00 & 0.00 & 0.00 \\
\hline $\mathrm{T}_{11}:$ Pyroxsulam & $18.75 \mathrm{~g} / \mathrm{ha}$ & 0.00 & 0.00 & 0.00 & 0.00 & 0.00 \\
\hline $\mathrm{T}_{12}:$ Halauxifen & $5.21 \mathrm{~g} / \mathrm{ha}$ & 0.50 & 0.25 & 0.00 & 0.00 & 0.00 \\
\hline $\mathrm{T}_{13}:$ Weed free & - & - & - & - & - & - \\
\hline $\mathrm{T}_{14}:$ Weedy check & - & - & - & - & - & - \\
\hline
\end{tabular}

Table 3: Effect of herbicides and their mixtures on plant height, number of tillers and dry matter accumulation of wheat

\begin{tabular}{|c|c|c|c|c|c|c|c|c|c|c|}
\hline \multirow[t]{2}{*}{ Treatments } & \multirow[t]{2}{*}{ Dose } & \multicolumn{3}{|c|}{ Plant height (cm) } & \multicolumn{3}{|c|}{ Number of tillers $\left(\mathrm{No} . / \mathrm{m}^{2}\right)$} & \multicolumn{3}{|c|}{$\begin{array}{c}\text { Dry matter accumulation } \\
\left(\mathbf{g} / \mathrm{m}^{2}\right)\end{array}$} \\
\hline & & 90 DAS & $\begin{array}{c}120 \\
\text { DAS }\end{array}$ & $\begin{array}{c}\text { At } \\
\text { harvest }\end{array}$ & 60 DAS & 90 DAS & $\begin{array}{c}120 \\
\text { DAS }\end{array}$ & 90 DAS & $\begin{array}{c}120 \\
\text { DAS }\end{array}$ & $\begin{array}{c}\text { At } \\
\text { harves }\end{array}$ \\
\hline $\mathrm{T}_{1}:$ Metsulfuron & $4 \mathrm{~g} / \mathrm{ha}$ & 76.7 & 89.0 & 93.0 & 90.0 & 85.5 & 73.8 & 121.51 & 271.66 & 296.11 \\
\hline $\mathrm{T}_{2}$ : Carfentrazone & $20 \mathrm{~g} / \mathrm{ha}$ & 75.9 & 88.0 & 92.0 & 88.8 & 84.4 & 72.8 & 119.93 & 268.13 & 292.26 \\
\hline $\mathrm{T}_{3}: 2,4-\mathrm{D}$ Ester & $500 \mathrm{~g} / \mathrm{ha}$ & 76.1 & 88.3 & 92.3 & 91.4 & 86.8 & 74.9 & 123.35 & 275.77 & 300.59 \\
\hline
\end{tabular}


Abdul Wahab Walizada et al, International Journal of Advances in Agricultural Science and Technology,

Vol.7 Issue.12, December-2020, pg. 81-97

ISSN: 2348-1358 Impact Factor: 6.057 NAAS Rating: $\mathbf{3 . 7 7}$

\begin{tabular}{|c|c|c|c|c|c|c|c|c|c|c|}
\hline $\begin{array}{l}\mathrm{T}_{4}: \text { Metsulfuron }+ \\
\text { carfentrazone }\end{array}$ & $4+20 \mathrm{~g} / \mathrm{ha}$ & 80.8 & 93.7 & 97.9 & 96.8 & 92.0 & 79.4 & 130.71 & 292.24 & 318.54 \\
\hline $\begin{array}{l}\mathrm{T}_{5}: \text { Metsulfuron+ } 2,4-\mathrm{D} \\
\text { Ester }\end{array}$ & $3+400 \mathrm{~g} / \mathrm{ha}$ & 80.9 & 93.8 & 98.0 & 97.2 & 92.4 & 79.7 & 131.24 & 293.41 & 319.82 \\
\hline $\begin{array}{l}\mathrm{T}_{6}: \text { Metsulfuron+ 2,4-D } \\
\text { Ester }\end{array}$ & $3+500 \mathrm{~g} / \mathrm{ha}$ & 81.4 & 94.4 & 98.6 & 103.1 & 97.9 & 84.5 & 139.13 & 311.05 & 339.04 \\
\hline $\begin{array}{l}\mathrm{T}_{7}: \text { Carfentrazone }+2,4-\mathrm{D} \\
\text { Ester }\end{array}$ & $\begin{array}{c}15+400 \\
\text { g/ha }\end{array}$ & 76.9 & 89.2 & 93.2 & 91.8 & 87.2 & 75.2 & 123.87 & 276.95 & 301.88 \\
\hline $\begin{array}{l}\mathrm{T}_{8}: \text { Carfentrazone }+2,4-\mathrm{D} \\
\text { Ester }\end{array}$ & $\begin{array}{c}15+500 \\
\mathrm{~g} / \mathrm{ha}\end{array}$ & 81.3 & 94.3 & 98.5 & 102.1 & 97.0 & 83.7 & 137.81 & 308.11 & 335.84 \\
\hline $\begin{array}{l}\mathrm{T}_{9}: \text { Halauxifen }+ \\
\text { pyroxsulam }\end{array}$ & $19.17 \mathrm{~g} / \mathrm{ha}$ & 81.0 & 94.1 & 98.3 & 97.2 & 92.4 & 79.7 & 131.24 & 293.41 & 319.82 \\
\hline $\begin{array}{l}\mathrm{T}_{10}: \text { Halauxifen }+ \\
\text { pyroxsulam }\end{array}$ & $23.96 \mathrm{~g} / \mathrm{ha}$ & 81.8 & 94.9 & 99.2 & 105.0 & 99.8 & 86.1 & 141.76 & 316.93 & 345.45 \\
\hline $\mathrm{T}_{11}:$ Pyroxsulam & $18.75 \mathrm{~g} / \mathrm{ha}$ & 75.8 & 87.9 & 91.9 & 87.9 & 83.5 & 72.0 & 118.61 & 265.19 & 289.06 \\
\hline $\mathrm{T}_{12}:$ Halauxifen & $5.21 \mathrm{~g} / \mathrm{ha}$ & 77.1 & 89.4 & 93.4 & 95.1 & 90.3 & 77.9 & 128.34 & 286.94 & 312.76 \\
\hline $\mathrm{T}_{13}:$ Weed free & -- & 82.1 & 95.2 & 99.5 & 106.6 & 101.2 & 87.4 & 143.86 & 321.64 & 350.59 \\
\hline $\mathrm{T}_{14}:$ Weedy check & -- & 72.0 & 83.5 & 87.3 & 81.1 & 77.1 & 66.5 & 108.11 & 244.81 & 266.84 \\
\hline $\mathrm{SEm} \pm$ & & 1.3 & 1.4 & 1.6 & 1.6 & 1.5 & 1.3 & 2.10 & 4.70 & 5.13 \\
\hline C.D.at $5 \%$ & & 3.6 & 4.2 & 4.4 & 4.7 & 4.4 & 3.8 & 6.31 & 14.11 & 15.38 \\
\hline
\end{tabular}




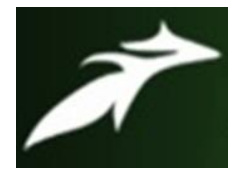

Abdul Wahab Walizada et al, International Journal of Advances in Agricultural Science and Technology,

Vol.7 Issue.12, December-2020, pg. 81-97

ISSN: 2348-1358

Impact Factor: 6.057

NAAS Rating: 3.77

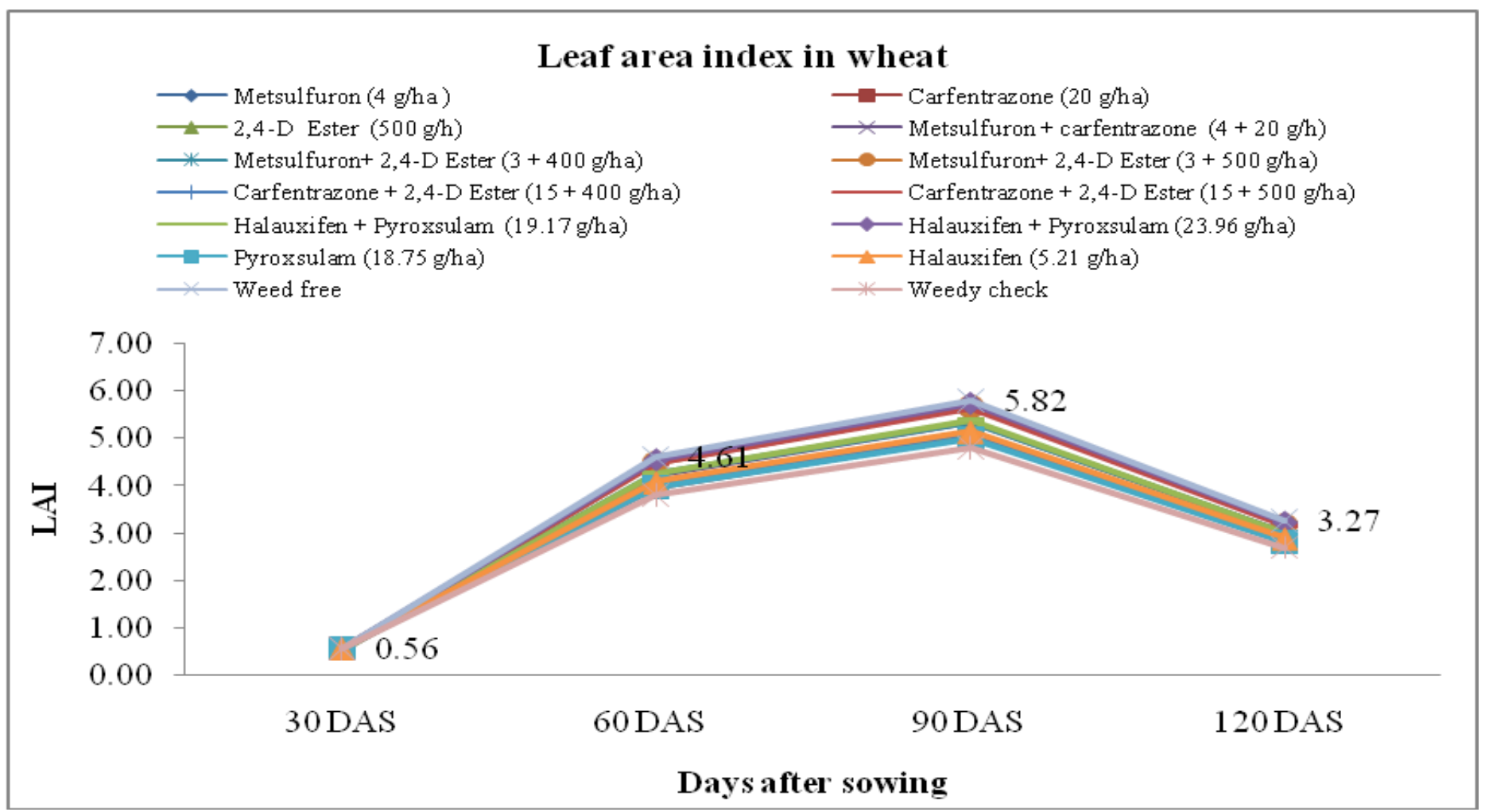

Fig. 1 : Leaf area index as affected by different herbicides and their mixtures in wheat at 30, 60, 90 and 120 days after sowing 
Abdul Wahab Walizada et al, International Journal of Advances in Agricultural Science and Technology,

Vol.7 Issue.12, December-2020, pg. 81-97

ISSN: 2348-1358

Impact Factor: 6.057

NAAS Rating: 3.77

Table 4: Effect of herbicides and their mixtures on yield attributes and crop yield of wheat

\begin{tabular}{|c|c|c|c|c|c|c|c|}
\hline Treatments & Dose & $\begin{array}{c}\text { No. of effective tillers } \\
\text { at harvest }\left(\mathbf{N o} / \mathbf{m}^{2}\right)\end{array}$ & $\begin{array}{c}\text { Spike } \\
\text { length } \\
(\mathrm{cm})\end{array}$ & $\begin{array}{c}\text { Grains/ } \\
\text { spike } \\
\text { (No.) }\end{array}$ & $\begin{array}{l}\text { Grain } \\
\text { yield } \\
\text { (kg/ha) }\end{array}$ & $\begin{array}{c}\text { Straw } \\
\text { yield } \\
\text { (kg/ha) }\end{array}$ & $\begin{array}{c}\text { Biological } \\
\text { yield } \\
\text { (kg/ha) }\end{array}$ \\
\hline $\mathrm{T}_{1}:$ Metsulfuron & $4 \mathrm{~g} / \mathrm{ha}$ & 361.5 & 10.20 & 59.29 & 4,622 & 7,900 & 12,522 \\
\hline $\mathrm{T}_{2}:$ Carfentrazone & $20 \mathrm{~g} / \mathrm{ha}$ & 357.0 & 10.20 & 58.52 & 4,560 & 7,831 & 12,391 \\
\hline $\mathrm{T}_{3}: 2,4-\mathrm{D}$ Ester & $500 \mathrm{~g} / \mathrm{ha}$ & 367.0 & 10.30 & 60.20 & 4,696 & 7,918 & 12,614 \\
\hline $\mathrm{T}_{4}$ : Metsulfuron + carfentrazone & $4+20 \mathrm{~g} / \mathrm{ha}$ & 389.0 & 10.90 & 63.79 & 4,971 & 8,248 & 13,219 \\
\hline $\mathrm{T}_{5}$ : Metsulfuron+ 2,4-D Ester & $3+400 \mathrm{~g} / \mathrm{ha}$ & 390.5 & 10.90 & 64.04 & 4,992 & 8,266 & 13,258 \\
\hline $\mathrm{T}_{6}:$ Metsulfuron+ 2,4-D Ester & $3+500 \mathrm{~g} / \mathrm{ha}$ & 414.0 & 11.60 & 67.90 & 5,290 & 8,379 & 13,669 \\
\hline $\mathrm{T}_{7}:$ Carfentrazone $+2,4$-D Ester & $15+400 \mathrm{~g} / \mathrm{ha}$ & 368.5 & 10.30 & 60.45 & 4,714 & 7,817 & 12,531 \\
\hline $\mathrm{T}_{8}:$ Carfentrazone $+2,4$-D Ester & $15+500 \mathrm{~g} / \mathrm{ha}$ & 410.0 & 11.50 & 67.26 & 5,243 & 8,335 & 13,578 \\
\hline $\mathrm{T}_{9}:$ Halauxifen + pyroxsulam & $19.17 \mathrm{~g} / \mathrm{ha}$ & 390.5 & 10.90 & 64.04 & 4,991 & 8,256 & 13,247 \\
\hline $\mathrm{T}_{10}$ : Halauxifen + pyroxsulam & $23.96 \mathrm{~g} / \mathrm{ha}$ & 422.0 & 11.60 & 69.18 & 5,395 & 8,466 & 13,861 \\
\hline $\mathrm{T}_{11}:$ Pyroxsulam & $18.75 \mathrm{~g} / \mathrm{ha}$ & 353.0 & 10.10 & 57.88 & 4,510 & 7,421 & 11,931 \\
\hline $\mathrm{T}_{12}:$ Halauxifen & $5.21 \mathrm{~g} / \mathrm{ha}$ & 382.0 & 10.70 & 62.63 & 4,883 & 7,916 & 12,799 \\
\hline $\mathrm{T}_{13}:$ Weed free & -- & 428.0 & 11.60 & 70.21 & 5,475 & 8,552 & 14,027 \\
\hline $\mathrm{T}_{14}:$ Weedy check & -- & 326.0 & 10.00 & 53.44 & 3,162 & 5,907 & 9,069 \\
\hline SEm \pm & & 6.5 & 0.17 & 1.03 & 86 & 110 & 141 \\
\hline C.D.at $5 \%$ & & 19.0 & 0.50 & 3.08 & 247 & 329 & 418 \\
\hline
\end{tabular}

